\title{
Effectiveness of School Leadership and Management Practices on Pupils' Outcomes in DRC Pilot Primary Schools
}

\author{
Corneille Luboya Tshiunza ${ }^{1,2}$ \\ ${ }^{1}$ Ph.D, School of Education, Department of Educational Economics and Management, Central China Normal \\ University, Wuhan, China \\ ${ }^{2}$ Teacher-Researcher, Faculty of Psychology and Eductaional Sciences, Departement of School Administration, \\ Management and Training Center, National Pedagogical University, Kinshasa, RD Congo. \\ corneilleluboya@outlook.fr

\begin{abstract}
The purpose of this quantitative study is to explain the possible impact of practices of leadership and management actors on student's outcomes. The survey was carried through a questionnaire to ascertain the school leadership and management practices of 100 members of school management of 27 primary pilot schools were linked to 1620 students' outcomes. The findings pointed out 39 significant practices in students outcomes among 82 selected practices. All these practices relate directly to the daily, monthly, trimestral and yearly duties of school leadership and management actors in DRC context. These practices are grouped into 3 components with 16 variables. The range from effective leadership and supervision of pedagogy; effective operational and strategic management of human, material and financial, information, and time resources available for school operations as well as an appropriate school environment.
\end{abstract}

Keywords: Pilot School, School Leadership, School Management, School Management and Leadership in DR Congo, School Management and Leadership Practices.

\section{INTRODUCTION}

Several studies have shown the relationship between school management, leadership and administration and school outcomes (Hallinger and Heck, 1998; Chevaillier, 2006; Pont, Nusche, and Moorman, 2008). Some studies are oriented on school management and leadership practices (Marzano, Waters and McNulty 2005; Collerette, Pelletier and Turcotte, 2013). Although most of these studies have shown that school management or leadership is linked with school outcomes or student well-being and academic performance directly and indirectly. Most of them were conducted in the context of developed countries.

However, in several developing countries as in Democratic Republic of Congo (DRC) the primary education quality and quantity are in declining. To address the situation, most of these countries have been working for the attainment of the millennium educational objectives for primary education. One such goal is the provision of quality education to $100 \%$ of children and youngest. This educational goal is aimed at ensuring access of elementary education by children and youngest as well as successful attainment of elementary education by guarding against dropouts (DRC-RESEN, 2015). In DRC, for example, the success rate in National Test of End of Primary School Studies (TENAFEP) has been lowest since 2000. It varies between 45 and 65\%. These trends vary from one province to the other. Despite the performance variations in inter and intra-school and educational provinces, the results of TENAFEP remain average. The longitudinal statistics indicate that the completion rate has been either stagnant or declining. Some schools differ significantly by their performance. Most of these are mainly primary pilot schools of Bandundu; Kongo Central and Kinshasa provinces (DRCRESEN, 2015, p.133-135). 
Thus, to ensure the success rate by our national schools the quality and quantity of teaching needs probing. Why has the success rate of the schools in these national examinations remained stagnant or in decline? Furthermore, how to improve internal effectiveness of educational system? What factors to take into account to improve the quality and quantity of academic success in primary schools? How the results of the national assessment can be used for the purpose of regulating internal efficacy of the educational system? The national reports showed that various actions such as curricula reforms and national itinerary school plans have been adopted to improve school outcomes however the impact has produced mixed results (DRC-RESEN, 2015).

In many educational systems of developed countries (USA, China, UK, Germany, France, Canada, Japan), the use of research in improving school effectiveness has guided several educational reforms. In this way, some reforms were positively affected the economic, social and industrial development of these countries. For example, in 1998 the results of the U.S. federal program showed that "harmonization of educational management practices affecting the various components of the school, especially of the class (...) brings an improvement of 55 percent of students' performance" (Gauthier, Bissonnette, Richard, and Djibo, 2003, p. 22).

In developing countries as in DRC, the study of influencing factors in student outcomes has not been seen as a national priority. The school governance reforms are initiated without referring to research results. This quantitative study made explicit the impact of practises of school leadership and management actors on higher performance schools in order to inspire those of lower performance schools. It also aims to test the nature and level of relation between components of school leadership and management practices, its variables and the students' outcomes. The study answers the following questions:

- What practices of school leadership and management' actors affect or influence positively three indicators of the students' outcomes?

- What components of school leadership and management practices have more influence on the success of the students?

\section{THEORITICAL FOUNDATION}

Firstly, the study define the terms pilot school, school leadership and school management and secondly to describe our theoretical foundation.

\section{Pilot School in DRC}

In the context of the DRC educational system, the Pilot Schools are officially accepted as excellent schools. They are also called "experimental or application schools". They are all public schools and receive state financing irregularly. The Pilot Schools are classified among the best schools. They are national standards in regard to their constancy of school performance competitiveness to internal school and national examinations. They have higher quality of teaching; the best organizational environments, the sustainable infrastructure and pedagogical equipment. They respect national school laws and policies and implement educational reforms.

These schools often are used by the technical services of the Ministry of Education in experimentation of teaching innovations and educational reforms. In line with pilot schools outcomes (in school and national school examinations and school management inspection), Luboya (2016) classifies: (i) Pilot Schools that have achieved high or excellent performance (from 100 to 81\%); (ii) Pilot Schools that have achieved ordinary or normal or satisfactory or acceptable performance (from 80 to 70\%) and (iii) Pilot Schools that have achieved low performance (below to 69\%).

\section{Difference between School Leadership and School Management}

The difference between leadership and management seems clear because leadership is supposed to pilot organizations in influencing attitudes, motivations and behaviours of people, the management is more closely associated with achievement of current activities (Bush and Glover, 2014). Dimmock (1999) made a distinction 
between leadership, management and administration of school by recognizing also that the powers and duties of school principals often include three activities. Whatever the definition of these terms, school principals are struggling to decide on the relative place to be given to a senior tasks level designed to improve the performance of school employees and students (leadership), the current guiding of the current activities (management) and to the activities of lower rank or level of school (administration). This definition classifies leadership in first position, followed by management and administration is relegated to last place in the hierarchy.

Sergiovanni, Kelleher, McCarthy and Fowler (2011, p.53), reports that some experts see management in the work and duties of school principals such as coordinating, directing, guiding, and supporting the work of others by setting objectives and performance assessment, supplying the available resources, establishing a psychological support climate, interacting widely with parents of students, proceeding through planning, programming, accounting, identifying and solving of interpersonal conflicts (teacher-teacher, teacher-management staff) and teacher-learner, solving the problems of the learners and by helping to get things well done by personnel.

However, school leadership activities go beyond the routine activities of school management. The behaviour of school principal shows the difference when it initiates and introduces the new structures, procedures, visions and goals (Lipham, 1964; Kotter, 1990; Zaleznik, 1977). The school leadership supposes that school principal influences the school employees with its new vision and goals, to motivate them to accomplish these goals with particular emphasis in the novelty and change. One more important difference is the school leadership focuses directly on qualitative and quantitative educational aspects. The school leadership addresses directly the problems and questions related to curricula, teaching quality, the difficulties of learning and evaluation of teaching. Thus, Sergiovanni et al. (2011) concluded that "leadership and Management in education should be examined together as similar concepts but still differently when it comes to leadership and administration in the general case" (Sergiovanni et al. 2011, p.53).

In this perspective, the school leadership deals with the teaching problems and quality issues and academic performance while the school management encompasses questions of education, the school environment and teaching, learning and work environment. It responds to the issues of the external public, looking for effectiveness, efficiency and balance in the rational use of resources in school. It resolves the social problems and analyses of the school organizational culture... A leader can be a manager while the manager is not a leader. Leader is focused on vision and change while manager is focused on procedure, regulation, polies and its implementations (Yukl, 2006). That's why Terry and Thomas (1978) stated that the management concerns the definition of educational objectives, the planning process, and provision of operational models, runs the organizational process, manages the school personnel, establishes budget, manage finances and directs and evaluates the school employees and student performance.

According to Pont et al. (2008, p.19), the leadership in school "is often used interchangeably with management and administration (...). Leadership can also include management and administration tasks. These three activities are so closely related that it is unlikely that one can be successful without others being also". These views are more correct in practice because it is not easy to separate the activities of administration (Administrator) management, (manager) and of leadership (leader) in school operations. However each of them can be more dominant than the others in one given context.

Whether administrator, leader or manager, each participates in the determination of the school policies, significantly influencing the members of the working group and use of available resources. Manager or leader is defined by the administrative process related to the functional managerial planning (work plan and budgeting), organizing, managing staff or staffing, leading or directing (leadership, communication, resolution of conflicts and decision making, coordination) and controlling (reporting, evaluation and execution). Often in an institution as school, it is the same person who plays different roles (manager, administrator, and leader). As such, the school principal relies on the management and leadership theories, administration principles to accomplish tasks. 
Effectiveness of School Leadership and Management Practices on Pupils' Outcomes in DRC Pilot Primary Schools

In practical perspective, the content of these three terms comprise of a set of strategies, principles, channels and instruments providing the knowledge and resources of information to make a hierarchical agent (school principal) more self-taught, intelligent, efficient, competent and more excellent compared to the demands and complexities of his tasks, roles, mandate, vision, mission, goals and objectives within an institution. On that note, the present study concentrates on school leadership and management practices.

\section{Overview on School Leadership and Management in DR Congo Context}

DRC has two types of schools: Public (90\%) and private (10\%). The first type is comprised of two groups of schools. $70 \%$ of national "conventional schools" managed by networks of religious organizations and $20 \%$ of national "official schools" managed directly by national, province and under province educational administration. But every private school is led and managed by its private administration council (DRC-RESEN, 2015).

The school administration and leadership in the DRC is a "hybrid or mixed system". There are the "National political leadership power hybrid" levels which are the central Governments (ministries of education), the secretariat-general and ad hoc technical services). In the "Provincial administration hybrid" level (governorates and provincial departments), DRC has the educational administration bodies of province and under province. In parallel to these governance bodies, although De Herdt et al., (2012) affirm that the "State provides the legal framework, laying out the organisation of educational administration, inspections and remuneration of staff, while the religious networks manage the educational institutions that they built, resourced, populated with teachers and also inspected according to their own internal criteria". $70 \%$ of national school networks are managing and leading by the both educational administration offices of province and under province and by school network offices of religious organizations (Catholic, Protestant, Kimbanguist, Islamic, Salvationist, Fraternity) in regard to Convention of School Management of 1977. In additional, DRC has also "financing sources of school operation hybrid" between three stakeholders (Parents by different school fees paid annually or termly: $77 \%$, State by annual educational budget: $19 \%$ and International Partners by humanitarian aids: $4 \%$ ). Their financing provide material (for construction of schools and equipment of classrooms), financial and human resources (expenditures of schools network offices operation, school district services operation and school employees remuneration) in national schools (DRC-RESEN, 2015; Poncelet et al. 2010; De Herdt and Titeca, 2016).

In DRC, from the period between 1960 and 2007, schools were led by "authoritarian school administration" from the colonial school system. School principals assisted by management staff manage and lead school without parents and pupils participation. The parents were claimed their management participation rights in school financial resources management. With introduction of democratic, the school governance reform initiated and implemented since 2008 (DRC-RESEN, 2014). It's the period of democratic school administration where school governance is exercised by School-based Management Committee (SBMC). It is composed of the school director, the assistant school director or head teacher, a teachers' representative, three representatives of parents (including the president of parent committee and at least one woman) and one representative of the student (with no voting rights). This SBMC is governance body which is assumed the management control of school resources and school operation. (DRC-MEPS-INC, 2011 cited by IRC, 2017).

In DRC, any primary school is led by school management team. One is composed of School principal "or school director", of Deputy School director, of changing teacher and school secretary (depending to size school). The school management team, specially school principal works within a dynamics of pressure between the directives, policies and administrative controls of State, the influences of school networks offices of religious organizations, the pressure of parents (requirement of teaching quality and pupils' performance in school and national examinations), the pressure of educational partners, of local community or environment (competitiveness between schools) and the pressure of industries (job market). Elonga, (2017a, p.34) state that "the nature of 
school leadership in the DRC context is (...) taking account of all the state and school network offices directives about what school principal need to do in order to lead their schools effectively". Hallinger and Heck (1998) show the powerful role of school management in the creation of effective teaching and learning conditions. It influences motivations, capabilities and the working conditions of the teaching staff which itself defines the pedagogical practices and students learning.

School principals with their teams lead and manage their school in line with daily, weekly, monthly, trimestral and yearly tasks which are clearly defined by ministry of education. But any school principal adds its own competences values in implementations. In this subject, the leadership and management skills of School Principals remains an important challenge for African countries such as the DRC. Bush and Oduro (2006, p.359) note that head teachers in Africa often work in poorly equipped schools with inadequately trained staff. The principals are appointed on the basis of their teaching record rather than their leadership potential. They are appointed without specific preparation, training and qualification (Bush and Glover, 2013, p.88). Most of school principal accessions to leadership position are usually on the basis of their experience as teachers. In their dominant tendency of daily work, school principals focus more in pedagogical and teaching leadership tasks (65\%); than human and social tasks, $20 \%$ and administration and management tasks, $15 \%$ (Luboya, 2016).

However, in some effective school in Ghana (Agezo, 2010, p.700) as in DRC, the school principals demonstrated their abilities to tap the wishes and needs of teachers, students, parents, district education officers, community members, and resources of their communities to achieve the school goals. Chevaillier, (2006, p.14) state school principals play a powerful role in helping to create conditions of effective teaching and learning. They influence the motivation, capabilities and the working conditions of teachers, which themselves influence teaching practices and learning of the students as well as affect the school's external public in order to enhance the image of the school. Thus, in DRC the school principal is considered as the first responsible of school operation. Although the study of Pasec (2011) shows the relationship between school principal and teacher's characteristics and student performance, the quantitative studies linking practices of school leadership and management and students' outcomes in DRC are infrequent.

\section{Overview on School Leadership and Management Practices related to Students Performances}

Several studies have focused on possible links between management and leadership practises in school field and how they influence academic performances.

Pont et al. (2008, p.19) emphasise the theoretical characteristics related to school leadership. It's about activities based on "organizational learning" that the school principal and his team must ensure. It is: (i) manage the instructional programs; (ii) monitoring and evaluation of teachers; (iii) supporting the professional development of teachers; (iv) support collaborative work; (v) define objectives, assessment and accountability counts (vi); mobilization and strategic management of resources (human, financial and material) and framing beyond the perimeter of school. In addition, Brault (2004, p.15) adds that the school climate (relational, education, justice, climate of belonging, security and school environment) is one of the most important indicators to test school effect, since it allows to explain some of the differences found between the schools compared to the academic success of students (Brunet and Corriveau, 1993). These features include the actor's school management practices.

Marzano, Waters and McNulty (2005) have analysed school management practices which affect students' performance. Their meta-analysis of 69 studies in the United States between 1970 and 2005 has an average correlation of 0.25 between 21 behaviours of school management and the academic performance of students. This analysis showed seven variables that are most strongly associated with the success are clearly focused on students, specifically on the behaviour and the quality of the relationships with and between them. These results are similar to those that have put an emphasis on the importance of creating a climate conducive to learning, where students can focus on their educational activities (Edmonds, 1979; Marzano, 2003). 
Collerette, Pelletier and Turcotte, (2013) reported that study of Robinson, Lloyd and Rowe, (2008) identified 78 variables. Fifty proved to be significantly associated with greater general efficiency of the school, including 25 in a more pronounced way. Some management practices would be so clearly associated with a higher performance of students. Many of them focus on the school operation, including supervision of students and school staff. The study of Collerette, Pelletier and Turcotte (2015, pp. 16-19) links the practices of school management or characteristics of the school environment in seven categories (control behaviours, relationshipcommunications, congruence, adaptation to the context, cohesion in the school, pedagogy or teaching) and the students' performance. More than half of these practices relate directly to behaviours of school management actors (school principals and assistants). Two categories of management practices most strongly associated with high results in test of MELS, with perseverance and reduction of absenteeism are a concentration on the control of behaviour as well as to facilitate good communications and good relationships in school. The most practices strongly associated with the reduction of school failures are those focused on the performance of students.

The school management practices are effective when they are influencing the school outcomes. One can be the success, the reduction of failures and absenteeism of both students and teachers. On this subject, Marzano, Waters and McNulty (2005) identified the school leadership practices that significantly influence the students' outcomes. Their research helped identify 21 practices that are related to the academic performance of students. From these findings, the study estimate that there are school management practices that: (i) influence the success of students; (ii) impact the reduction of failures; (iii) reduce the rate of absenteeism. Each school is a complex system influenced by several factors. One is directly and indirectly related to outcomes - success, failure, absenteeism - of students (figure 1).

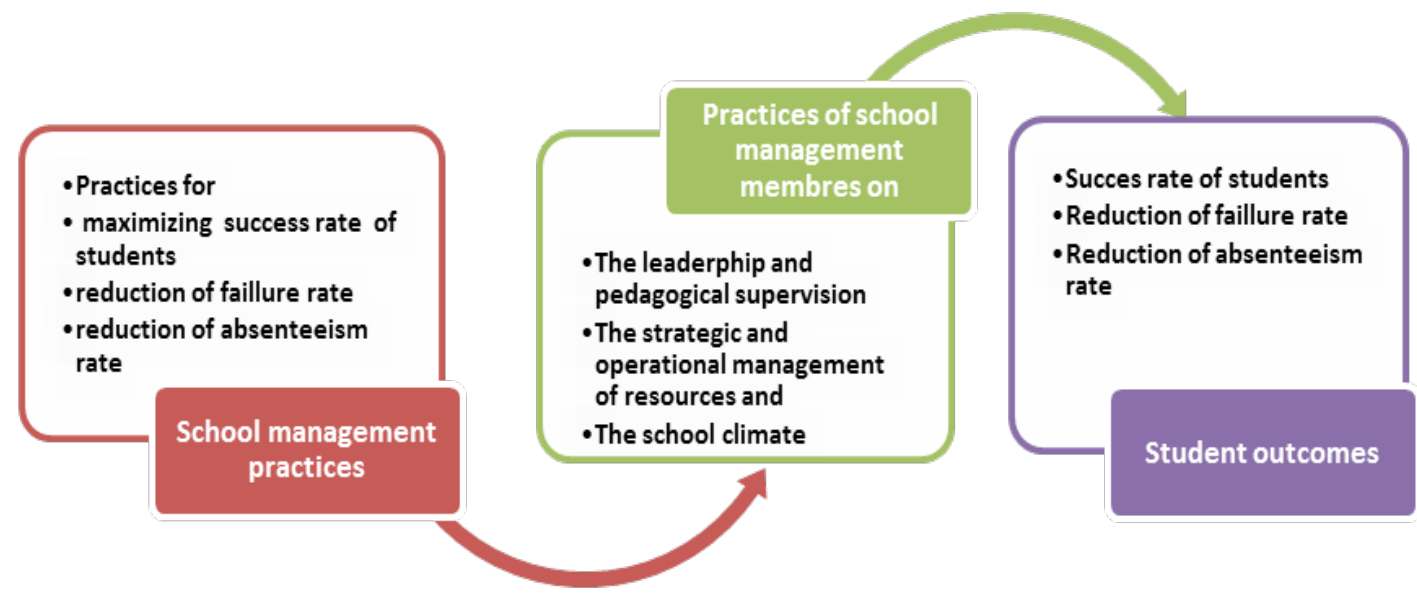

Fig1. Model of school management practices

Figure 1 illustrates the model of school management practices from literature review. This model does not minimize the impact of the socio-economic characteristics of students on academic success, community, individual differences and parents. These characteristics are considered to be protective factors. The study model is designed to explain and predict the results of students from the school management practices.

\section{Methodology}

\section{Population and Sample}

There are 261 pilot primary schools in DR Congo. The study extracted the sample from two levels. At the first level, the study extracts 27 schools, or 10.3 percent $(13$ schools in Kinshasa, 6 schools in Bandundu and 8 in Kongo-Central). In the first level, the study used judgment or convenience sampling by natural groups. The 
selected schools classified as experimental have been asked to take part in research. From all school management members of 27 schools, the researchers extracted, at the second level, the stratified random sampling consisting of fourth categories of participants: School Director ( $N=27)$, Deputy School Director ( $=27$ ), School Secretary $(\mathrm{N}=25)$ and Changing Teacher or "Surnumerary" $(\mathrm{N}=19)$ and the pupils' outcomes of these schools $(\mathrm{N}=1620)$. At this level, the study considers the principle of $95 \%$ confidence and 5\% error risk of a stratified random sample (Mayer and Quellet, 1991).

\section{Methodological Strategy and Instrument of Data Collection}

On the strategies of data collection and processing, the study used the survey method (Ngongo, 1999). The document analysis and the questionnaire have been used as data collection techniques. The investigation includes two major steps: it is about pre-survey and the survey.

\section{The Pre-Survey}

The pre-survey step was checked and adapted to the instruments of the primary and secondary data that precedes actual survey. In this stage, the study has developed the first version of questionnaire and submitted it to 20 school management members in order to test its consistency. Checking the consistency of the questionnaire, the first analysis related to the correlations between items pertaining to each one of these dependent variables. It indicates that the items (questions) of all selected variables of our questionnaire comprise satisfactory levels of homogeneity. Because, the index of internal coherence relating to alpha of Cronbach varies for the underscales between .72 and .80 , with an average equalizes to .80 , and reaches .89 for the total factor. It comes out from it just as the scale comprises an adequate temporal stability, since the correlation test-retest goes from .70 to .80 for the under-scales, with an average of .77 , and is of .83 for the total factor. The second analysis shows a fidelity slightly lower for the items of dimension of school operational and strategic management practices (Alpha $=0.67$; Mean $=4,12 ; \mathrm{OR}=0,59$ ). Lastly, concerning dimension of school climate, the fidelity of the items is low (Alpha $=0.68$; Mean $=6,25 ; \mathrm{OR} .=0,60$ ). All of these results indicate that our questionnaire has consistency feature.

\section{Actual Survey}

The survey was carried out through the administration of the questionnaire. According to the guidelines of Javeau (1986), the study used two types including: the direct and indirect administration. The first type is the interviewee himself notes his answers to the questions, whereas the indirect administration where we note the answers to the questions the subject interviewed provided.

The final version of questionnaire included 82 statements (questions) with a five scale of Likert, ranging from "strongly disagree" to "strongly in agreement. This instrument of data collection has been designed according to the objectives of the study, to theoretical framework and to instrument model of school management practices (Collerette, Lauzier and Schneider, 2013 and Collerette et al. 2013). Three dimensions were evaluated: (i) the practices of pedagogy leadership and supervision (manage the curricula; monitoring and evaluation of teachers; supporting the professional development of teachers, support collaborative work, define objectives and regular evaluation of learning and progress of students; high expectations of behaviour and the results of the students; focus on the rights and responsibilities of students), including 22 questions such as "school management regularly convenes meetings of school board, monitoring of implementation of its resolutions and recommendations"; (ii) the practices of operational and strategic management of resources (mobilization and participatory and transparent management of human, financial and material resources available centred on the success and well-being of students and effective supervision and obligation of giving account and reports), including 42 questions or practices such as "school management puts in place concrete measures for school and student success planning"; and (iii) practices related to the organizational and social climate of school 
Effectiveness of School Leadership and Management Practices on Pupils' Outcomes in DRC Pilot Primary Schools

(relational, education, justice, climate of belonging, security and school environment), including 18 questions such as "school management ensures that order and discipline are maintained in a satisfactory manner in school".

From the beginning of June 2016, the researchers administered the questionnaire. They have collected statistics of academic success, failure and absenteeism of students in these schools. The survey took two months, the time interval between the beginnings of October until the end of November 2016.

\section{Management and Analysis of Data}

The data collected was managed and processed using the software IBM SPSS (Version 22). An aggregate score of success associated with the practices of school management was generated by the method of the composite index (Velez, Johnson \& Cowen, 1989; Vitaro \& Gagnon, 2000). We proceeded to the Cronbach's alpha, Correlation and ordinary least squares or linear least squares (OLS) in logistics and binary regression. The study considers alpha $(\alpha)=0.05(\mathrm{p}<.05$ or $5 \%)$.

Thus, no significant correlations were given a score 0 , the significant correlations but low effect (from 0 to .25 ) received a score 1, the moderate (from .26 to .40) a score of two and the strongest correlations (from .41) a score 3. And second coding was based on the directives of Collerette et al, (2013, pp. 20-21). Between 93 and 123 scores practices strongly influence the results; between 62 and 92 partially affect the results; between 31 and 61 lower influence results and between 0 and 30 the practices influence the results limitedly. These scores were standardized and combined to achieve overall scores indicating the robustness of the links with the success of the students. The minimum score of each of the variables was 0 and maximum was 39 . The maximum score indicates that reporting management practice is strongly associated with indicators of success. Only the variables with scores composite are higher than 10 of 39 were adopted.

\section{Confidentiality and Ethical Considerations}

Several exchanges were made with the competent authorities of DR Congo educational system around the month of January 2016. Many official documents were acquired from the ministry of primary education and from provinces and under provinces educational administration. Upon our request, the under-provincial chiefs link the researchers with the chiefs of pool of education inspection (from them the researchers collect the reports of pilot schools inspection) and with the school principals of the 27 pilot primary schools. The researchers took measures of ethics aiming at privileging the climate of trust between the participants. With an aim of putting the participants in confidence, the researchers guaranteed the anonymity of participants in the questionnaire administration and data analysis process. All the participants had freedom of choice to take part into the investigation.

\section{RESULTS}

After survey, management and analysis of data, expected results are presented according to the research questions as follows:

Table1. Management practices have a positive effect on the students' performance according to the scores and correlations

\begin{tabular}{|c|c|c|}
\hline Practices of school management & Score & Rank (r) \\
\hline \multicolumn{3}{|l|}{ Leadership and supervision of pedagogy or teaching (school management) } \\
\hline It supervises whole activities of the pedagogical units and organizing models lessons & 30 & 3 \\
\hline It gives attention to the pedagogical practices of teachers & 19 & 2 \\
\hline It exercises pressures to the teaching quality and the professional performance of the teachers & 32 & 3 \\
\hline It motivates teachers to improve regularly, their teaching practices & 18 & 1 \\
\hline
\end{tabular}


Effectiveness of School Leadership and Management Practices on Pupils' Outcomes in DRC Pilot Primary Schools

\begin{tabular}{|c|c|c|}
\hline $\begin{array}{l}\text { It regularly convenes teaching or pedagogical meetings and ensures the implementation of } \\
\text { its resolutions and proceeds to the educational visits of the classes twice in a month }\end{array}$ & 32 & 3 \\
\hline $\begin{array}{l}\text { It puts high expectations to quality of the learning of students and ensures that the success } \\
\text { of the students is the priority of the school }\end{array}$ & 31 & 3 \\
\hline It controls and monitors the update of teaching documents of teachers every day & 16 & 1 \\
\hline $\begin{array}{l}\text { It distributes the manuals, the handbooks, the equipment and materials of teaching to } \\
\text { teachers in classes }\end{array}$ & 22 & 2 \\
\hline It encourages and assists teachers in their efforts to improve the quality of their teaching & 33 & 3 \\
\hline It controls the planning and execution of the disciplines or matter provided of curricula & 26 & 2 \\
\hline It puts in place concrete measures in order to achieve curricula aims & 22 & 2 \\
\hline It involves in the control of documents of students (notebooks, homework and books) & 28 & 3 \\
\hline \multicolumn{3}{|l|}{\begin{tabular}{|c|} 
Operational and strategic management of resources (school management) \\
\end{tabular}} \\
\hline $\begin{array}{l}\text { It regularly convenes meetings of school board, monitoring of implementation of its } \\
\text { resolutions and recommendations }\end{array}$ & 30 & 3 \\
\hline $\begin{array}{l}\text { It plans, organizes, controls, directs and regulates the tasks of individual and collective work } \\
\text { of school employees, teachers and students }\end{array}$ & 16 & 1 \\
\hline $\begin{array}{l}\text { It analyses the results of internal and external evaluations and discusses the results of } \\
\text { assessments of learning at staff meetings }\end{array}$ & 32 & 3 \\
\hline $\begin{array}{l}\text { It mobilizes the financial resources and material from the school budget adopted by the } \\
\text { school board and school management committee meeting }\end{array}$ & 17 & 1 \\
\hline $\begin{array}{l}\text { It manages effectively human resources (recruitment, selection, hiring, salary, transfer, leave, } \\
\text { promotion, training, evaluation, discipline) according to the legal dispositions }\end{array}$ & 17 & 1 \\
\hline It respects and enforces implementation of directives, laws and official instructions & & 1 \\
\hline $\begin{array}{l}\text { It defines the objectives of the school, mobilizes and motivates staff to work to achieve these } \\
\text { educational goals }\end{array}$ & 29 & 3 \\
\hline $\begin{array}{l}\text { It requires each school staff to achieve high performance and students to succeed in national } \\
\text { tests }\end{array}$ & 30 & 3 \\
\hline $\begin{array}{l}\text { It devotes rationally the resources (human, , material, financial and information) available on } \\
\text { the success of students according to school operation need and satisfaction of the teachers }\end{array}$ & 28 & 3 \\
\hline $\begin{array}{l}\text { It provides internal communication (interpersonal and services) and external with } \\
\text { effectiveness }\end{array}$ & 16 & 1 \\
\hline $\begin{array}{l}\text { It promotes and defends the interests of the school with various authorities and external } \\
\text { public }\end{array}$ & 22 & 2 \\
\hline $\begin{array}{l}\text { During the school year, school management convenes the meetings of parents and evaluates } \\
\text { the learning difficulties, problems of disciplines and performance of students }\end{array}$ & 25 & 2 \\
\hline $\begin{array}{l}\text { It associates the parents, teachers and local educational associations in the school operation } \\
\text { and activities and in the decision-making process }\end{array}$ & 27 & 3 \\
\hline It put in place effective measures to achieve the success of the school planning & 29 & 3 \\
\hline It invests more to improving of the results of students & 31 & 3 \\
\hline $\begin{array}{l}\text { It effectively coordinates activities of the various stakeholders in the school (Disciplinary } \\
\text { board, pedagogical or teaching units meeting, assessment deliberation meeting and } \\
\text { Committee of parents' meeting...) }\end{array}$ & 15 & 1 \\
\hline It focuses on the problems and issues of the school employees & & 2 \\
\hline It works quickly on the school problems and in satisfying student need & 29 & 3 \\
\hline $\begin{array}{l}\text { It asserts itself in its principal role and knows the strengths, opportunities, threats and } \\
\text { weaknesses of the school }\end{array}$ & 21 & 2 \\
\hline
\end{tabular}


Effectiveness of School Leadership and Management Practices on Pupils' Outcomes in DRC Pilot Primary Schools

\begin{tabular}{|c|c|c|}
\hline \multicolumn{3}{|l|}{ Organizational and social climate of school (school management) } \\
\hline $\begin{array}{l}\text { It motivates teachers (with salary bonuses, congratulations) and students (praise and } \\
\text { psychological rewards) and animates social life in school }\end{array}$ & 13 & 1 \\
\hline $\begin{array}{l}\text { It attends and helps socially, teachers and students in fortunate and unfortunate } \\
\text { circumstances }\end{array}$ & 21 & 2 \\
\hline It puts a lot of the strategies to guarantee the right of students in schooling & 30 & 3 \\
\hline It puts a lot of energy to create a pleasant and favourite environment of students & 32 & 3 \\
\hline It is very attentive to the issues, difficulties of students and solves them & 31 & 3 \\
\hline It communicates effectively with students & 14 & 1 \\
\hline $\begin{array}{l}\text { It demonstrated consistency, justice and self-sacrifice in the management of the behaviours } \\
\text { of the students }\end{array}$ & 15 & 1 \\
\hline $\begin{array}{l}\text { It clarifies the rules and directives on the behaviour of students in the school and control the } \\
\text { applicability and implementation of these school rules }\end{array}$ & 27 & 3 \\
\hline It ensures that order and discipline are maintained satisfactorily in school & 31 & 3 \\
\hline It establishes a quiet, orderly and safe environment for students and their leaning & 20 & 2 \\
\hline
\end{tabular}

Three performance indicators selected (the performance of the schools is grouped in two groups of schools between $70 \%-100 \%$ and $0 \%$ to $69 \%$ in the TENAFEP, rates of failure in the same national tests and absenteeism rate) and 82 practices of school management of 27 pilot primary schools were associated in a correlation matrix (Collerette et al, 2015). This has allowed establishing a categorization of leadership and management practices with links to the indicators of success. This table shows the management practices of the members of school leadership having positive relationships with students' results according to the axes of school management and school operation in DR Congo (table 1).

Table2. Correlations between the indicators of success and the components of school leadership and management

\begin{tabular}{|c|c|c|c|}
\hline Categories of school leadership and management practices & Successes & Failures & Absenteeism \\
\hline \multicolumn{4}{|c|}{ Leadership and supervision of pedagogy or teaching (5 components) } \\
\hline $\begin{array}{l}\text { Curriculum management and support to the collaboration of the teaching } \\
\text { units meetings }\end{array}$ & $.305^{* *}$ & $.341^{*}$ & .082 \\
\hline $\begin{array}{l}\text { Definition of objectives and assessment of the quality of teaching and } \\
\text { learning }\end{array}$ & $.482^{* *}$ & $.575^{* *}$ & .095 \\
\hline Pedagogical organization and regular teaching supervision of teachers & $.635^{*}$ & $.631^{*}$ & $-762^{* *}$ \\
\hline High expectations of behaviour and results of students & $.505^{* *}$ & $531^{* *}$ & $-.751^{* *}$ \\
\hline $\begin{array}{l}\text { Continuing training and monitoring of professional development of } \\
\text { teachers }\end{array}$ & $.541^{*}$ & $585^{* *}$ & $-.464^{* *}$ \\
\hline \multicolumn{4}{|c|}{ Operational and strategic management of resources (6 components) } \\
\hline $\begin{array}{l}\text { Mobilization of financial and material resources according to the needs of } \\
\text { the school operation and institutional communication effectiveness }\end{array}$ & $.364^{* *}$ & $.323^{* *}$ & $.386^{* *}$ \\
\hline $\begin{array}{l}\text { Effective utilisation of financial resources and materials focused on the } \\
\text { success of students and teachers' job satisfaction }\end{array}$ & $.718^{* *}$ & $.559^{* *}$ & $-.649^{* *}$ \\
\hline $\begin{array}{l}\text { Participatory management and regular evaluation of the functioning of the } \\
\text { school }\end{array}$ & $.531^{* *}$ & $.451^{* *}$ & $-.356^{* *}$ \\
\hline Organisational learning & $.376^{* *}$ & $.242^{* *}$ & $320^{* *}$ \\
\hline Effective implementation of the official guidelines and school law & $.439 * *$ & $.571^{*}$ & .090 \\
\hline
\end{tabular}


Effectiveness of School Leadership and Management Practices on Pupils' Outcomes in DRC Pilot Primary Schools

\begin{tabular}{|l|c|c|c|}
\hline $\begin{array}{l}\text { Involvement of stakeholders (parents, educational associations and others) } \\
\text { and transparency in management }\end{array}$ & $.801^{* *}$ & $.785^{* *}$ & \multicolumn{2}{|c|}{$.442^{* *}$} \\
\hline \multicolumn{1}{|c|}{ Organizational and social climate of school (5 components) } \\
\hline Relational climate & $.537^{* *}$ & $0,409^{* *}$ & $.551^{*}$ \\
\hline Educational climate & $.418^{* *}$ & $0,490^{* *}$ & $.553^{*}$ \\
\hline Climate of justice & $.442^{* *}$ & .020 & $.451^{* *}$. \\
\hline Climate of belonging & $.364^{* *}$ & -.008 & $390^{* *}$. \\
\hline Climate of security and environment & $.423^{* *}$ & $.451^{* *}$ & $.512^{* *}$ \\
\hline
\end{tabular}

${ }^{*} p \leq 0.05$ and ${ }^{* *} p \leq 0.01$

Two categories of school leadership and management practices are most strongly associated with high results in the TANAFEP and reduction of the failures are those who focused on the leadership and supervision of pedagogy or teaching as well as the operational and strategic management of school resources. The practices most strongly associated with the reduction of absenteeism are those focused on organizational and social climate of school.

Table3. School Leadership and Management Practices as Factor Predicting of School Performance

\begin{tabular}{|c|c|c|c|c|}
\hline \multicolumn{5}{|c|}{\begin{tabular}{|c}
$\begin{array}{c}\text { Significant Results from OLS Predicting Primary Pilot School performance (using two groups: Higher } \\
\text { and Lower Performance schools as Dependent variable) }\end{array}$ \\
\end{tabular}} \\
\hline Independent Variables & $b(C I)$ & $S E$ & $\beta$ & $p$-value \\
\hline \multicolumn{5}{|c|}{ Leadership and supervision of pedagogy or teaching } \\
\hline $\begin{array}{l}\text { Definition of objectives and assessment of the quality of teaching and } \\
\text { learning }\end{array}$ & $.310(.205, .415)$ & .053 & .312 & $.000^{* *}$ \\
\hline Pedagogical organization and regular teaching supervision of teachers & $.259(.121, .398)$ & .070 & .248 & $.000 * *$ \\
\hline High expectations of behaviour and results of students & $.177(.047,306)$ & .066 & .257 & $.008^{* *}$ \\
\hline $\begin{array}{l}\text { Continuing training and monitoring of professional development of } \\
\text { teachers }\end{array}$ & $.173(.076, .269)$ & .049 & .270 & $.001^{* *}$ \\
\hline \multicolumn{5}{|c|}{ Operational and strategic management of resources } \\
\hline $\begin{array}{l}\text { Effective utilisation of financial resources and materials focused on the } \\
\text { success of students and teachers job satisfaction }\end{array}$ & $.156(.113, .199)$ & .022 & .434 & $.000 * *$ \\
\hline $\begin{array}{l}\text { Participatory management and regular evaluation of the functioning } \\
\text { of the school }\end{array}$ & $.269(.200, .339)$ & .035 & .456 & $.000^{* *}$ \\
\hline Effective implementation of the official guidelines and school law & $.483(.368, .599)$ & .059 & .484 & $.000^{* *}$ \\
\hline $\begin{array}{l}\text { Involvement of stakeholders (parents, educational associations and } \\
\text { others) and transparency in management }\end{array}$ & $.229(.181, .277)$ & .024 & .535 & $000 * *$ \\
\hline \multicolumn{5}{|c|}{ Organizational and social climate of school } \\
\hline Relational climate & $.087(-.155,-.018)$ & .035 & -.164 & $.014^{*}$ \\
\hline Educational climate & $.073(.011, .135)$ & .031 & .155 & $.021^{*}$ \\
\hline Climate of security and environment & $.118(.061, .175$ & .029 & .266 & $.000^{* *}$ \\
\hline
\end{tabular}

${ }^{*} \mathrm{p} \leq 0.05$ and ${ }^{* *} \mathrm{p} \leq 0.01$

Table 3 shows the OLS results for model predicting the dependent variable (school performance). In the models of focal variables combined, statistically significant at the $95 \%$ levels of confidence. In generally, the 
OLS regression results presented show some initial findings. Firstly, practices of school management members predict the school outcomes generally. Secondly, four on six components of Leadership and supervision of pedagogy or teaching; four on six components of operational and strategic management of resources and three on five components of organizational and social climate of school predict the success of the students in TENAFEP.

\section{DiscusSion}

In Congo, the students' achievement rates in their schooling or in TENAFEP are either stagnant or decreasing. These rates are average for most national primary schools but they reached 80 to 100 percent in pilot primary schools. The researchers thought that the improving success rate and reducing failure and absenteeism rates must pass by the educational reforms based on the results of empirical studies.

A decade ago, Marzano et al. (2005) identified 21 behaviours of school management have a positive impact on the students' academic performance. They also showed that seven variables are strongly associated with students' success are clearly focused on students, specifically on behaviour and quality of relationships with and among themselves. In 2015, Collerette et al. (2015) confirmed that the links between the seven categories of management practices and indicators of success are relatively constant. Variables representing the categories focus on behaviour control and the dual relationships-communication are those that generate the highest correlations. A concentration on the quality of climate generates a stronger relationship with positive indicators on the success and perseverance (Collerette et al. 2015, pp. 16-19). The present study has identified 39 most significant school leadership and management practices among 82 selected practices. All these practices relate directly to the daily, monthly, trimestral and yearly duties or tasks of school management of actors (school principals, their assistants and personnel support services of management and school operation) in RDC context.

Based on legal and official dispositions of school administration and management in DR Congo, 82 identified school management practices were grouped into three components and 16 variables. The leadership and supervision of pedagogy or teaching (organization and regular teaching or pedagogical supervision of teachers, high expectations of behaviour and student performances; continuous training and professional development of teachers and definition of objectives and assessment of the quality of teaching and learning) and the operational and strategic management of resources available in school (effective and efficient use of financial and material resources centred on student success and job satisfaction of teachers; involvement of stakeholders: parents, educational associations and others, transparency in the management of schools; participatory management and regular assessment of the functioning of the school) are the two components with influence strongly positive with success and failure reduction but negative with the reduction of student absenteeism in school. The most significant management practices are strongly associated with the reduction of absenteeism are those focused on the social and organizational climate of school (relational, education, justice and security and environmental climates).

Moreover, the results of the regression analysis involving management practices and indicators of success showed that the majority of the variables of the three components are predictive of the success of the students in TENAFEP and reduction of failure. In the same way the study of Robinson et al, (2008) reported the relationship between leadership style and effectiveness of the school. It is the concentration of efforts on the pedagogy and administration that produces a higher positive effect in terms of success against a focus on relationships.

These results attest to the relational variability between the dimensions of management practices of schools and indicators of the success in TENAFEP. These findings question the notion of teaching quality or the effectiveness of school by effective school management in DR Congo and redefine its critical variables, since school management focuses on teaching quality with aim to improve academic achievement in quality and quantity, 
reducing failure rates and absenteeism in school. The effective leadership and supervision of pedagogy; the effective operational and strategic management human, material and financial, information and time resources available for the school operation as well as the organizational and social climate appropriate of school are receipts that influence the indicators and predict the quantitative (70 to 100 percent) and qualitative success of students in TENAFEP.

However, it should be noted that each management practice, alone, do not have a positive or predictive effect, without other management practices in school operation. Several studies are pronounced on the usefulness and relevance of the management practices of all the actors involved in school on performance of the students. In addition, the most influential management practices differ from one area to other (developing or developed countries) according to the school laws and contexts, the habits and customs of an educational system, compared to another, depending on forces and limits of its actors and their characteristics (Marzano et al, 2005 et Collerette et al. 2015). Some teachers, for example, could be motivated and stimulated by some management practices of school principals and others might feel constrained. Beyond all, the study mentions also the differential effects of these practices on students; the characteristics of schools and classes. However, the causal links between management practices and indicators of pupils' outcomes is demonstrated.

\section{CONCLUSION}

The results described relationships between the schools' leadership and management practices and indicators of students' outcomes. These practices are grouped into three explanatory components of the school operation. They are associated with the three indicators of student outcomes. These relationships have led to a linear explanation and the causal relationships have been demonstrated. The authorities of the DRC educational system as well as schools leaders and managers can rely on these significant practices in order to improve their schools and students outcomes. The educational reforms must take account of the results compared with the objectives to maximize success, reduce the failure and absenteeism rate. However, should not assimilate the generated associations of correlation or regression analysis to unchanging causal relationships. These practices with the strong influence or predictive ability are not unchanging factors compared to the others. Therefore, these significant practices should be considered as factors that could be combined to maximize the chances of success as that magical finding by their specific nature.

The possibility to generalize the results of this research is restricted by methodological limits. The survey was conducted only on members of schools' management committee. Surveys of teachers would allow a possible triangulation of data for more understanding of the indicators of the students' outcomes in primary education. Any attempt to generalize the results should be considered more carefully given the nature of the research sample at first level. This transversal research does not allow for the study of these variables in a longitudinal perspective, or even prioritize them in terms of direct links.

The results of this study and its limitations may guide future research efforts in three directions: the use of discriminating measures of effectiveness; identification of differential effects of the management practices, school context and characteristics in primary, secondary and higher education levels; a finer understanding of management practices required to meet the potentially different needs of teachers and students whether they simply expect to avoid failure or wish incremental success.

\section{REFERENCES}

1. Agezo, C.K. (2010). Female leadership and school effectiveness in junior high schools in Ghana. Journal of Educational Administration 48(6): 689-703.

2. Brault, M.C. (2004). L'influence du climat sur les résultats des élèves : effet- établissement ou perception individuelle, Mémoire DES, Montreal : Université de Montréal, www.f-d.org/climatefficacité-brunet.htm 
Effectiveness of School Leadership and Management Practices on Pupils' Outcomes in DRC Pilot Primary Schools

3. Brunet, L. \& Corriveau, L. (1993). Climat organisationnel et efficacité de sept polyvalentes au Québec en milieu métropolitain, Revue des sciences de l'éducation, vol. XIX, no3, p.483 à 499.

4. Bush, T., \& Glover, D. (2016). School leadership in West Africa: Findings from a systematic literature review. Africa Education Review, 13(3-4), 80-102.

5. Bush, T., \& Glover, D. (2014). School leadership models: what do we know? School leadership \& Management, 34(5), 553-557

6. Bush, T. and Oduro T. (2006). New principals in Africa: Preparation, induction and practice. Journal of Educational Administration 44(4): 359-375.

7. Chevaillier, T. (2006). Les nouveaux rôles des chefs d'établissements dans l'enseignement secondaire. Paris: UNESCO.

8. Collerette P., Pelletier D. et Turcotte G. (2015). Les pratiques de gestion des directions d'école secondaire sont-elles liées à la réussite des élèves? Revue canadienne de l'éducation, 38:1.

9. Collerette P., Pelletier D. et Turcotte G. (2013). Recueil de pratiques des directions d'écoles secondaires favorisant la réussite des élèves, Québec : PUQ.

10. Collerette, P., Lauzier, M., \& Schneider, R. (2013). Le pilotage du changement. Québec : PUQ.

11. De Herdt T. and Titeca, K. (2016). Governance with Empty Pockets: The Education Sector in the Democratic Republic of Congo, Development and Change 47(3): 472-494.

12. De Herdt, T., Titeca, K., \& Wagemakers, I. (2012). Make schools, not war? Donors'rewriting of the social contract in the DRC, Development Policy Review, 30(6), 681- 701.

13. Dimmock, C. (1999). «Principals and School Restructuring: Conceptualising Challenges as Dilemmas», Journal of Educational Administration, 37 (5), 441-462.

14. Edmonds, R. R. (1979). Effective Schools for the Urban Poor. Educational Leadership, 37, 15-24.

15. Elonga Mboyo, J. P. (2017a). Comparative Leadership: Pathways, Scope and Values in DRC-English 'Urban' Schools. Doctoral Thesis, UK: Sheffield Hallam University.

16. Gauthier, C. Bissonnette, S., Richard, M. et Djibo, F. (2003). Pédagogies et écoles efficaces dans les pays développés et en développement, Association pour le développement de l"éducation en Afrique Biennale de l'ADEA.

17. Hallinger, P. and Heck R. (1998), « Exploring the Principal's Contribution to School Effectiveness: 19801995 », School Effectiveness and School Improvement, 9 (2), 157-191.

18. Javeau, C. (1985). Enquête par questionnaire, Bruxelles : ULB.

19. Kotter, J-P. (1990). A Force for Change, New-York, Harvard Business School Press

20. Lipham, James (1964). Leadership and Administration in Daniel Griffiths (ed) Behavioural Science and Educational Administration, University Of Chicago Press

21. Luboya Tshiunza C. (2016). Management et leadership de la classe, Papier de conférence scientifique à la Sous-coordination des écoles conventionnées catholiques de Ndjili, Kinshasa: Université Pédagogique Nationale.

22. Marzano, R., Waters T. and McNulty B. (2005). School Leadership That Works: From Research to Results, Alexandria: Association for Supervision and Curriculum Development. 
Effectiveness of School Leadership and Management Practices on Pupils' Outcomes in DRC Pilot Primary Schools

23. Mayer, R. et Ouellet, F. (1991). Méthodologie de recherche pour les intervenants sociaux, Montréal: Gaëtan Morin.

24. Marzano, R.J. (2003). What Works in School: Translating Research into Action. Alexandria: Association for Supervision and Curriculum Development.

25. Marzano, R.J., Waters, T., McNulty, B.A. (2005). School Leadership that Works: from Research to Results. Alexandria: Association for Supervision and Curriculum Development.

26. Ngongo Dishasi P.R. (1999). La recherche scientifique en éducation, Bruxelles, Louvain-la-Neuve, Academica.

27. Poncelet et al., (2010). La survie de l'école primaire congolaise (RDC) : héritage colonial, hybridité et résilience, Autrepart (2) n 54, p. 23-41, http://www.cairn.info/revue-autrepart-2010-2-page-23.htm

28. Pont, B., Nusche, D. et Moorman, H. (2008). Améliorer la direction des établissements scolaires. Volume 1: Politiques et pratiques, Paris: OCDE.

29. DRC-RESEN (2015). Revue des Dépenses Publiques du secteur de l'éducation en République Démocratique du Congo: Une Analyse d'Efficience, d'Efficacité et d'Équité, Banque Mondiale.

30. DRC-MEPS-INC. (2011). « Arrêté Ministériel NMINEPSP/CABMIN/0799/2011» in IRC (2017). Improved Management and Accountability: Conditions for Better Access and Quality of Primary Education in the DRC? https://www.rescue.org/sites/default/files/document/1310/drceducationgovernancefinaljanuary2017. pdf

31. Robinson, V., Lloyd, C. A., \& Rowe K. J. (2008). The impact of leadership on student outcomes: An analysis of the differential effects of leadership types. Educational Administration Quarterly, (44)5, 635-674.

32. Sergiovanni, T., Kelleher, P., McCarthy M., and Fowler C. (2011). Educational Governance and Administration, 6th Edition, San Antonio, Los Angeles and Miami: Pearson.

33. Terry G. and Thomas J.B. (1978). International dictionary of education, London, Falmer Press.

34. Velez, C.N., Johnson, J., and Cowen, P. (1989). A longitudinal analysis of selected risk factors for childhood psychopathology. Journal of the American Academy of Child and Adolescent Psychiatry, 28, 861-864.

35. Vitaro, F. \& Gagnon, C. (2000). Prévention des problèmes d'adaptation chez les enfants et les adolescents. Québec: PUQ.

36. Yukl, G. (2006). Leadership in Organisation, $6^{\text {th }}$ Ed., New Jersey: Prentice Hall.

37. Zaleznik, A., (1977). Managers and Leaders: Are They Different? Harvard Business Review, May-June.

Citation: Corneille Luboya Tshiunza. "Effectiveness of School Leadership and Management Practices on Pupils' Outcomes in DRC Pilot Primary Schools". American Research Journal of Humanities and Social Sciences, vol 4, no. 1, 2018, pp. 1-15.

Copyright (c) 2018 Corneille Luboya Tshiunza. This is an open access article distributed under the Creative Commons Attribution License, which permits unrestricted use, distribution, and reproduction in any medium, provided the original work is properly cited. 